\title{
ANALYSIS OF ELECTRICAL AND OPTICAL FLUCTUATIONS OF LIGHT-EMITTING DIODES BY CORRELATION METHOD
}

\author{
V. Palenskis, J. Matukas, and B. Šaulys \\ Radiophysics Department, Vilnius University, Saulètekio 9, LT-10222 Vilnius, Lithuania \\ E-mail: vilius.palenskis@ ff.vu.lt, jonas.matukas@ ff.vu.lt
}

Received 16 September 2009; revised 13 November 2009; accepted 18 December 2009

\begin{abstract}
A detailed analysis of electrical and optical fluctuations of high power $(3 \mathrm{~W}$ ) light-emitting diodes (LEDs) is presented. A special attention was paid to the measurement and interpretation of simultaneous correlation coefficient between electrical and optical fluctuations. The simultaneous correlation coefficient was measured not only over frequency range from $10 \mathrm{~Hz}$ to $20 \mathrm{kHz}$, but for the first time in every one-octave frequency band. The presented technique not only permitted to determine the correlation coefficient dependence on frequency, but also to estimate what part to correlation coefficient is produced by low-frequency fluctuations with $1 / f, 1 / f^{\alpha}$, and Lorentzian type spectra, respectively. From the obtained experimental and calculation results it is determined that the simultaneous correlated part of electrical and optical fluctuations for these LEDs is related with the defect presence in the active layer or at its interfaces, while the uncorrelated part of electrical noise is caused by parallel leakage channel in other places, and the resistance of this channel is many times higher than that of $p-n$ junction.

Keywords: white light-emitting diodes (LEDs), electrical fluctuations, optical fluctuations, correlation coefficient, correlation in one-octave frequency band
\end{abstract}

PACS: $72.70 .+\mathrm{m}, 85.60 . \mathrm{Jb}$

\section{Introduction}

Nitride compound semiconductors are widely used in light-emitting diodes (LEDs) for ultraviolet and visible spectra [1-6]. However, the nitride-based LED fabrication encounters some problems such as a large number of threading dislocations in the active layer. These dislocations originate from the interface between $\mathrm{GaN}$ and substrate due to lattice mismatch. This leads to nonradiative recombination processes that lower the lightemitting device efficiency and accelerate device ageing [7].

Investigation of noise is known to yield a valuable information on dominant physical processes in semiconductor materials and structures [8-12]. In this paper we present a comprehensive investigation of noise characteristics of high power white LEDs. The scope of investigation was to determine the correlation coefficient between electrical and optical fluctuations over the measured frequency range and in every one-octave frequency band, to estimate what part to correlation coefficient is produced by low-frequency fluctuations with $1 / f, 1 / f^{\alpha}$, and Lorentzian type spectra, respectively, and to discuss the origin of electrical and optical noise sources in these devices.

\section{Investigated LEDs and measurement details}

A high power $(3 \mathrm{~W})$ white light-emitting diodes, fabricated on the base of blue quantum-well InGaN LEDs with their surface covered by an YAG:Ce ${ }^{+3}$ phosphor layer emitting broadband yellow light, have been investigated. Operation current of these LEDs is up to $1 \mathrm{~A}$.

Output light power, current-voltage and noise characteristics were measured at room temperature in wide forward current range. For noise investigation of optoelectronic devices it is important to measure both the optical noise (LED emitted light flow fluctuations, detected by photodiode) and electrical noise (LED terminal voltage fluctuations). We used the Cooley-Tukey fast Fourier transformation for measurements of noise spectra in the frequency range from $10 \mathrm{~Hz}$ to $20 \mathrm{kHz}$. The absolute values of power spectral densities of electrical and optical fluctuations were evaluated by comparing with thermal noise levels of reference resistors $R_{\mathrm{e} 1}$ and $R_{\mathrm{e} 2}$, respectively (Fig. 1). The own noise of measurement system was eliminated from noise level measurement by short-circuiting the input of low noise amplifier. The noise level of photodetector was caused by thermal noise of load resistor $R_{\mathrm{ph}}$. A special attention was paid to the measurement and interpretation of 


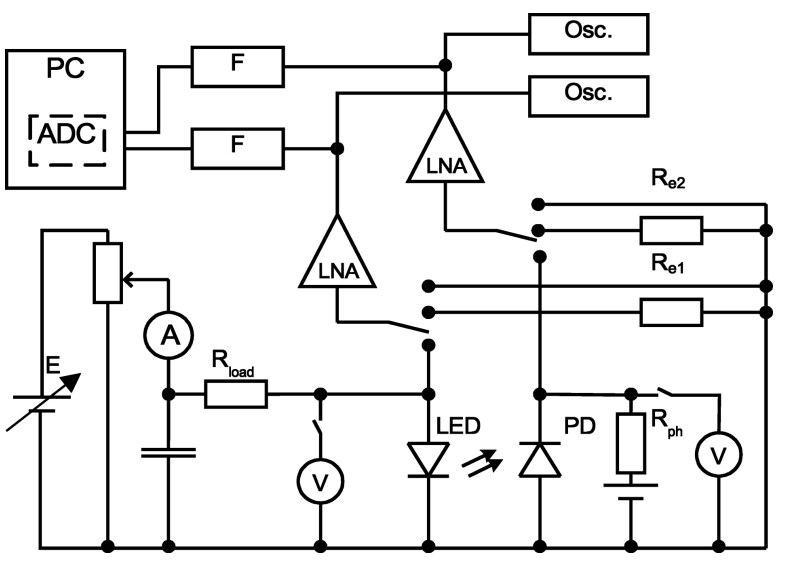

Fig. 1. Measurement circuit: $L N A$ low noise amplifier, $F$ bandpass filter, Osc. oscilloscope, $A D C$ National Instruments ${ }^{\text {TM }}$ PCI 611 card.

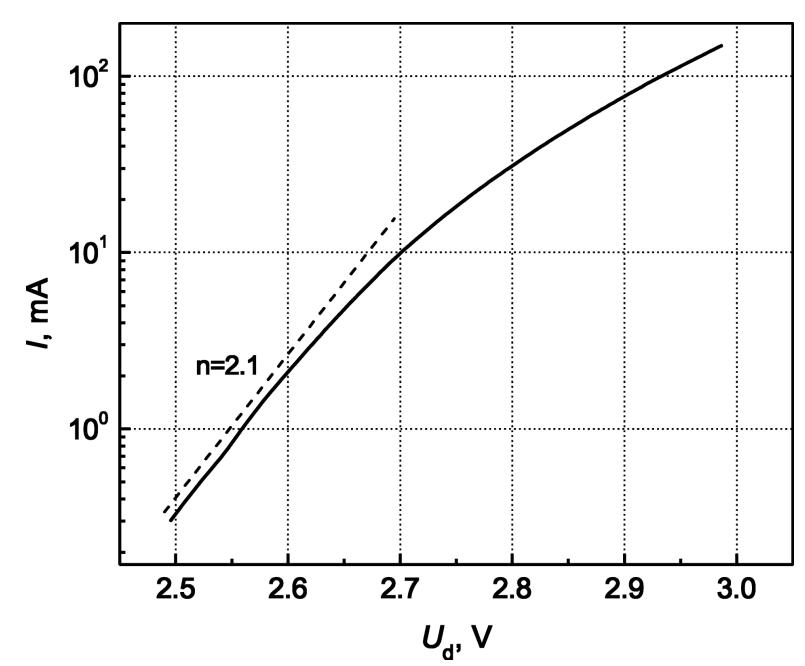

Fig. 2. Typical current-voltage characteristic of investigated white LEDs ( $n=2.1$ is the nonideality factor).

simultaneous correlation coefficient between electrical and optical fluctuations. In order to evaluate the correlation coefficient, the electrical and optical fluctuations were measured simultaneously, i. e. the processing of the both noise signals was performed using two identical channels comprised of low noise amplifiers, filter systems, analog digital converter (National Instruments $^{\mathrm{TM}}$ PCI 6111 card) (Fig. 1). The correlation coefficient was directly measured not only over the frequency range from $10 \mathrm{~Hz}$ to $20 \mathrm{kHz}$, but also in every one-octave frequency range with one-octave digital filters, having the following central frequencies $f_{\mathrm{c}}(\mathrm{Hz})$ : $15,30,60,120,240,480,960,1920,3840,7680$, and 15360 .

A typical current-voltage characteristic of the investigated white LEDs is shown in Fig. 2. The nonideality factor $n$ of the current-voltage characteristic $I=I_{0} \exp \left[e U_{\mathrm{d}} /(n k T)\right]$ is very close to the value per-

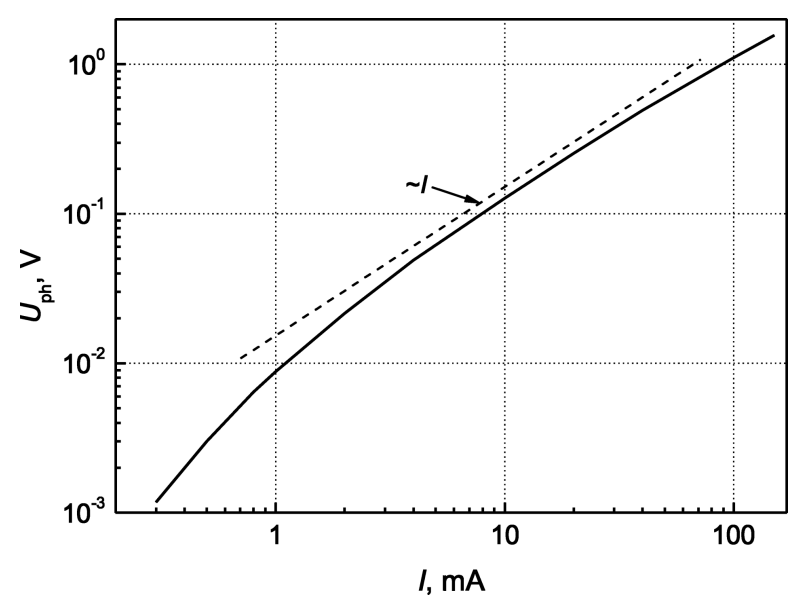

Fig. 3. Photodetector voltage (proportional to the emitted light flowrate) dependence on d. c. current of LED.

tinent to charge carrier recombination process in $p-n$ junction. A deviation from the exponential dependence is due to the voltage drop in series resistance of the LED. An emitted light intensity dependence on d.c. current is presented in Fig. 3: here the photodetector voltage is proportional to the emitted light flow (or to the output power).

\section{Decomposition of experimental noise spectra into components and evaluation of variances}

Power spectral densities of electrical and optical fluctuations of LEDs and laser diodes (LDs) at low frequencies $f$ can be presented as a sum of independent spectral components of $1 / f, 1 / f^{\alpha}$, Lorentzian type (for the dominant recombination processes with recombination time $\tau$ ) and shot noise:

$$
\begin{aligned}
S_{\mathrm{el} \mathrm{sum}}(f)= & \frac{A_{\mathrm{el} 1 / f}}{f}+\frac{A_{\mathrm{el} 1 / f^{\alpha}}}{f^{\alpha}}+\frac{A_{\mathrm{el} \mathrm{gr}} \tau}{1+(2 \pi f \tau)^{2}} \\
& +S_{\mathrm{el} \mathrm{sh}}, \\
S_{\mathrm{ph} \mathrm{sum}}(f)= & \frac{A_{\mathrm{ph} 1 / f}}{f}+\frac{A_{\mathrm{ph} 1 / f^{\alpha}}}{f^{\alpha}}+\frac{A_{\mathrm{ph} \mathrm{gr}} \tau}{1+(2 \pi f \tau)^{2}} \\
& +S_{\mathrm{ph} \mathrm{sh}},
\end{aligned}
$$

where quantities $A_{j}$ define the intensities of noise components. In general, the number of spectral components with Lorentzian type spectrum depends on complexity of the total spectrum. Such presentation is very useful for further analysis of noise properties because it assumes that noise sources with $1 / f, 1 / f^{\alpha}$, and Lorentzian type spectra and shot noises are statistically independent. An example of the assumed decomposition of the optical noise spectrum is shown in 


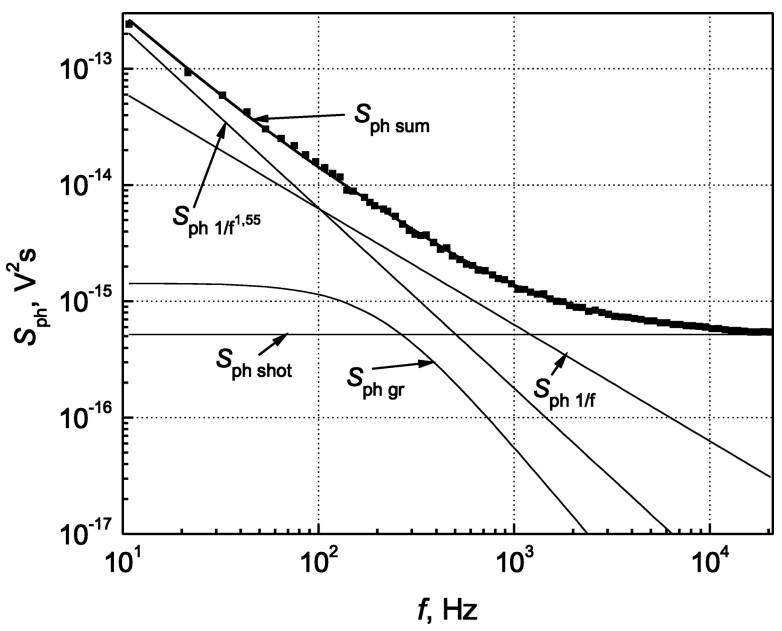

Fig. 4. Optical noise spectrum decomposition into components. Dots are measurement results.

Fig. 4. The experimental results (symbols) are approximated by Eqs. (1) and (2) (Figs. 5 and 6, solid lines). So, according to the obtained decomposition, the total electrical and optical fluctuations (also including the noise of measurement system) can be expressed respectively in the following way:

$$
\begin{aligned}
u_{\mathrm{el} \mathrm{total}}(t)= & u_{\mathrm{el} 1 / f}(t)+u_{\mathrm{el} 1 / f^{\alpha}}(t)+u_{\mathrm{el} \mathrm{gr}}(t) \\
& +u_{\mathrm{el} \mathrm{sh}}(t)+u_{\mathrm{el} \mathrm{syst}}(t), \\
u_{\mathrm{ph} \mathrm{total}}(t)= & u_{\mathrm{ph} 1 / f}(t)+u_{\mathrm{ph} 1 / f^{\alpha}}(t)+u_{\mathrm{ph} \mathrm{gr}}(t) \\
& +u_{\mathrm{ph} \mathrm{sh}}(t)+u_{\mathrm{ph} \mathrm{syst}}(t),
\end{aligned}
$$

where lower indices at fluctuation components indicate their electrical or optical origin (el and ph respectively) and the type of noise $-1 / f, 1 / f^{\alpha}$, Lorentzian (gr), shot (sh), or measurement system's own one (syst).

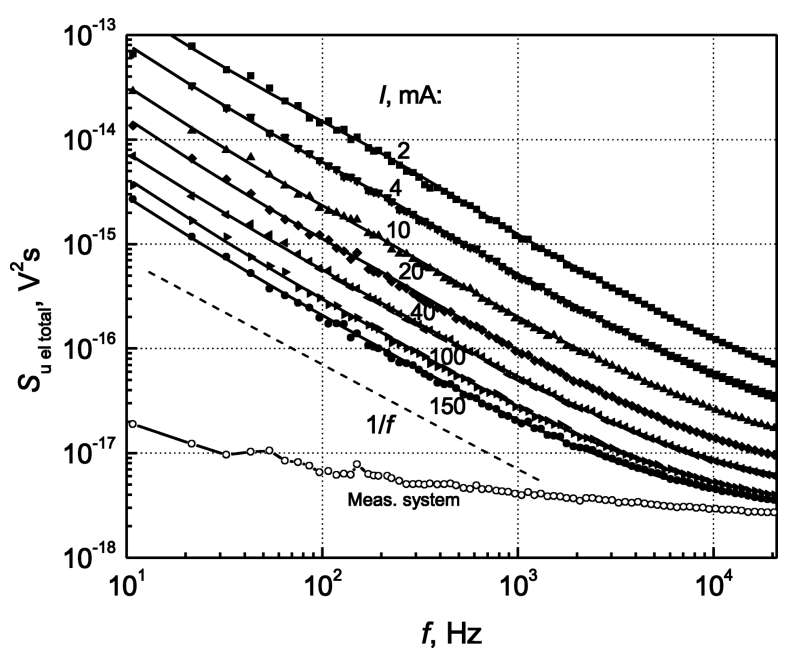

Fig. 5. Electrical noise spectra of white light-emitting diode at different d.c. currents. Dots are experimental results, solid lines are calculated by Eq. (1).
According to expressions (3) and (4) the electrical and optical fluctuation variances can be defined as

$$
\begin{aligned}
\sigma_{\mathrm{el} \mathrm{total}}^{2}= & \sigma_{\mathrm{el} 1 / f}^{2}+\sigma_{\mathrm{el} 1 / f^{\alpha}}^{2}+\sigma_{\mathrm{el} \mathrm{gr}}^{2} \\
& +\sigma_{\mathrm{el} \mathrm{sh}}^{2}+\sigma_{\mathrm{el} \mathrm{syst}}^{2}, \\
\sigma_{\mathrm{phtotal}}^{2}= & \sigma_{\mathrm{ph} 1 / f}^{2}+\sigma_{\mathrm{ph} 1 / f^{\alpha}}^{2}+\sigma_{\mathrm{ph} \mathrm{gr}}^{2} \\
& +\sigma_{\mathrm{ph} \mathrm{sh}}^{2}+\sigma_{\mathrm{ph} \mathrm{syst}}^{2},
\end{aligned}
$$

where every variance component $\sigma_{j}^{2}$ in frequency range from $f_{1}$ to $f_{2}$ now can be determined from the noise spectral components:

$$
\sigma_{j}^{2}=\int_{f_{1}}^{f_{2}} S_{j}(f) \mathrm{d} f .
$$

For the further estimation of the correlation coefficient in one-octave frequency band $\left(f_{2}=2 f_{1}\right)$ it is useful to estimate the variances of electrical and optical noise components with various spectra in this frequency band:

$$
\sigma_{1 / f \text { oct }}^{2}\left(f_{\mathrm{c}}\right)=\int_{f_{1}}^{f_{2}} \frac{A_{1 / f}}{f} \mathrm{~d} f=A_{1 / f} \ln \frac{f_{2}}{f_{1}}=A_{1 / f} \ln 2,
$$

$$
\begin{aligned}
& \sigma_{1 / f^{\alpha} \text { oct }}^{2}\left(f_{\mathrm{c}}\right)=\int_{f_{1}}^{f_{2}} \frac{A_{1 / f^{\alpha}}}{f^{\alpha}} \mathrm{d} f= \\
& =\left(\frac{3}{4}\right)^{\alpha-1} \frac{2^{\alpha-1}-1}{\alpha-1} \frac{A_{1 / f^{\alpha}}}{f_{\mathrm{c}}^{\alpha-1}} \quad(\text { here } \alpha \neq 1),
\end{aligned}
$$

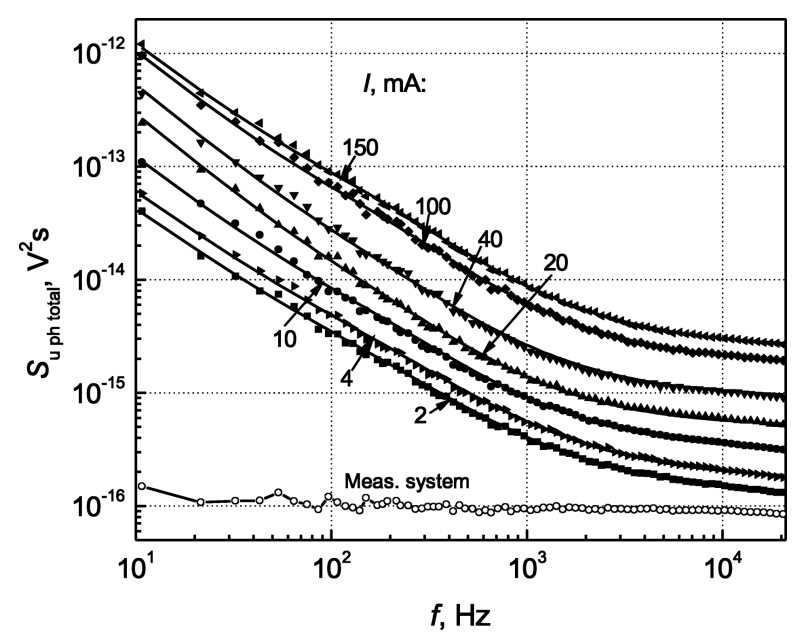

Fig. 6. Optical noise spectra of white light-emitting diode at different d.c. currents. Dots are experimental results, solid lines are calculated by Eq. (2). 


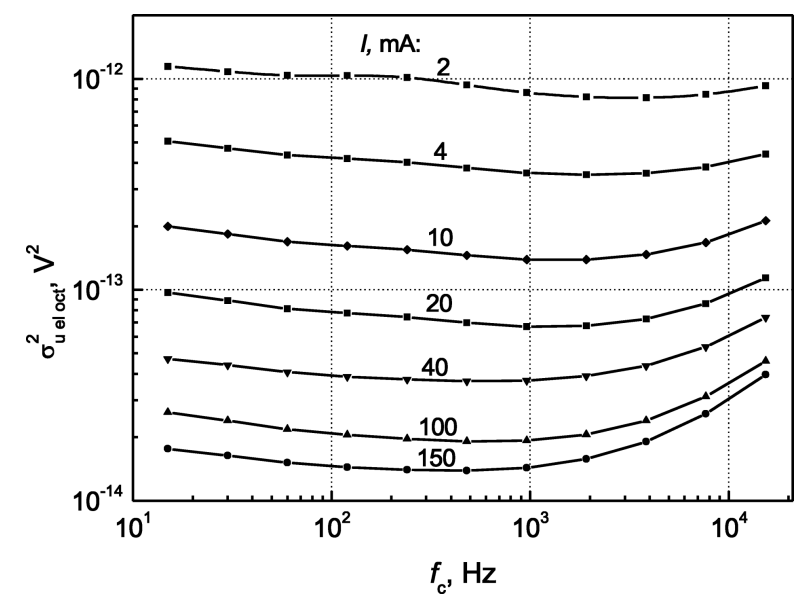

Fig. 7. Electrical noise variance dependence on central frequency $f_{\mathrm{c}}$ of octave filter at different d. c. currents.

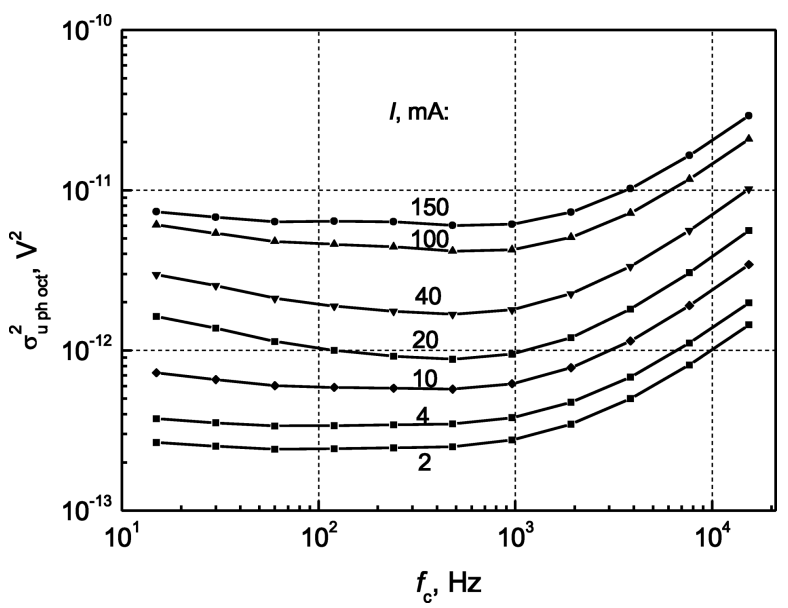

Fig. 8. Optical noise variance dependence on central frequency $f_{\mathrm{c}}$ of octave filter at different d.c. currents.

$$
\begin{aligned}
& \sigma_{\text {gr oct }}^{2}\left(f_{\mathrm{c}}\right)=\int_{f_{1}}^{f_{2}} \frac{A_{\mathrm{gr}} \tau}{1+(2 \pi f \tau)^{2}} \mathrm{~d} f \\
& =\frac{A_{\mathrm{gr}}}{2 \pi}\left[\arctan \frac{8 \pi \tau f_{\mathrm{c}}}{3}-\arctan \frac{4 \pi \tau f_{\mathrm{c}}}{3}\right], \\
& \sigma_{\text {sh oct }}^{2}\left(f_{\mathrm{c}}\right)=\int_{f_{1}}^{f_{2}} S_{\mathrm{sh}} \mathrm{d} f=\frac{2}{3} S_{\mathrm{sh}} f_{\mathrm{c}}
\end{aligned}
$$

where $f_{\mathrm{c}}$ is the central frequency of the one-octave frequency band filter. The electrical and optical noise variances for voltage fluctuations in one-octave frequency band were calculated using Eqs. (1), (2), (5)-(11); the obtained dependences on central frequency $f_{\mathrm{c}}$ of octave filter at different d. c. currents are presented in Figs. 7 and 8 . An increase of variances at higher $f_{\mathrm{c}}$ is related with the larger contribution of noise with constant spectral density.

\section{Evaluation of correlation coefficient between electrical and optical fluctuations}

The simultaneous correlation coefficient was measured on the basis of this expression:

$$
r=\frac{\left\langle u_{\text {el total }}(t) \cdot u_{\text {ph total }}(t)\right\rangle}{\left(\sigma_{\text {el total }}^{2} \cdot \sigma_{\text {ph total }}^{2}\right)^{1 / 2}},
$$

where brackets $\langle\ldots\rangle$ mean averaging both by time and by number of realizations, and $\sigma_{\text {el total }}^{2}=\left\langle u_{\text {el total }}^{2}(t)\right\rangle$, $\sigma_{\text {ph total }}^{2}=\left\langle u_{\text {ph total }}^{2}(t)\right\rangle$ are the total variances of electrical and optical fluctuations.

Let us present the correlation function in the following way:

$$
\left\langle u_{\mathrm{el} \mathrm{total}}(t) \cdot u_{\mathrm{ph} \text { total }}(t)\right\rangle=\sum_{j=1}^{3}\left\langle u_{\mathrm{el} j}(t) \cdot u_{\mathrm{ph} j}(t)\right\rangle,
$$

where index $j=1$ describes the correlation function for $1 / f$ type fluctuations, $j=2$ for $1 / f^{\alpha}$, and $j=$ 3 for Lorentzian type fluctuations; here we have also taken into account that the components of shot, thermal, and measurement system noise are uncorrelated. We also assumed that in the general case not all lowfrequency electrical fluctuations (for example, with $1 / f$ type, or $1 / f^{\alpha}$ type, or with Lorentzian type spectrum) can be completely correlated with optical fluctuations; contact or electrical noises in passive layers of LED do not cause the emitted light intensity fluctuations, i. e., every spectral component of low-frequency electrical noise can be presented as a sum of correlated and uncorrelated parts:

$$
\begin{aligned}
S_{\mathrm{el} j}(f)= & S_{\mathrm{el} j \text { cor }}(f)+S_{\mathrm{el} j \text { uncor }}(f)= \\
& d_{j} S_{\mathrm{el} j}(f)+\left(1-d_{j}\right) S_{\mathrm{el} j}(f),
\end{aligned}
$$

here quantity $d_{j}$ shows what part of spectral component $S_{\mathrm{el} j}(f)$ of electrical noise is related with emitted light intensity fluctuations.

The correlation coefficient (12) in the overall measured frequency range, after Eqs. (13) and (14), can be presented as

$$
r=\frac{\sum_{j=1}^{3}\left(d_{j} \sigma_{j \mathrm{el}}^{2} \cdot \sigma_{j \mathrm{ph}}^{2}\right)^{1 / 2}}{\left(\sigma_{\text {el total }}^{2} \cdot \sigma_{\mathrm{ph} \mathrm{total}}^{2}\right)^{1 / 2}}
$$




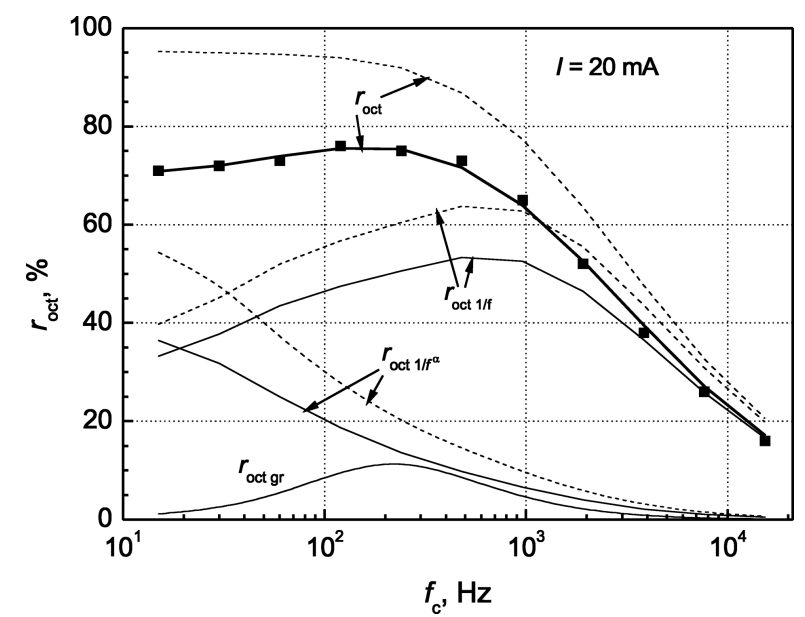

Fig. 9. Correlation coefficient between electrical and optical fluctuations in one-octave frequency band $r_{\text {oct }}$ dependence on central frequency $f_{\mathrm{c}}$ of octave filter at $I=20 \mathrm{~mA}$. Dots are measurement results; thick solid line is calculation data by Eq. (16) with $d_{1}=$ $0.7, d_{2}=0.45$, and $d_{3}=1$; thin solid lines are contributions to correlation coefficient of $1 / f, 1 / f^{\alpha}$, and Lorentzian type fluctuations; dashed lines present the case as if $1 / f, 1 / f^{\alpha}$, and Lorentzian type electrical and optical fluctuations were completely correlated $\left(d_{1}=d_{2}=d_{3}=1\right)$.

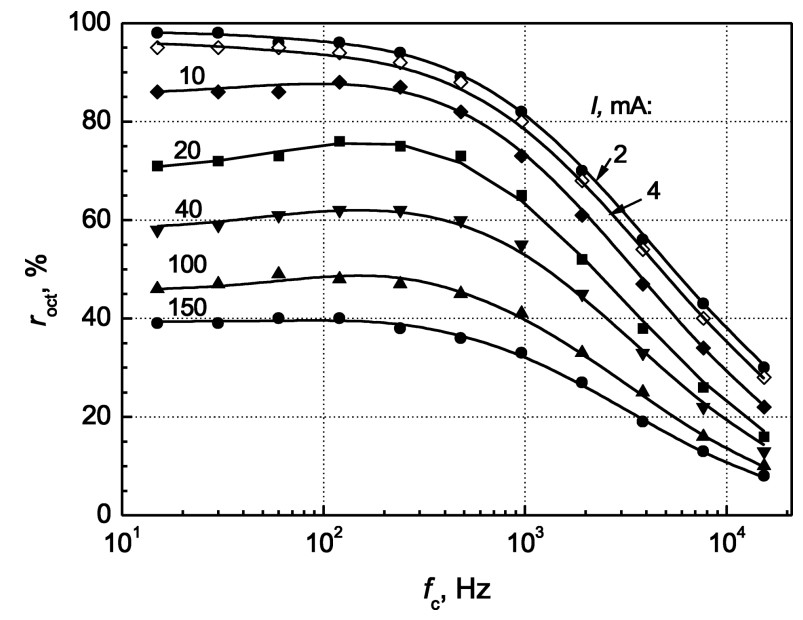

Fig. 10. Correlation coefficient between electrical and optical fluctuations in one-octave frequency band dependence on central frequency $f_{\mathrm{c}}$ of octave filter at different d.c. currents. Dots are measurement results, solid lines are calculation data by Eq. (16).

and respectively, for every one-octave frequency band

$$
r_{\text {oct }}=\frac{\sum_{j=1}^{3}\left(d_{j} \sigma_{j \text { el oct }}^{2} \cdot \sigma_{j \text { ph oct }}^{2}\right)^{1 / 2}}{\left(\sigma_{\text {el total oct }}^{2} \cdot \sigma_{\text {ph total oct }}^{2}\right)^{1 / 2}} .
$$

An example of the correlation coefficient in oneoctave frequency band $r_{\text {oct }}$ dependence on the central frequency of octave filter and contributions of $1 / f$, $1 / f^{\alpha}$, and Lorentzian type fluctuations are shown in Fig. 9. The quantities $d_{j}$ were determined by compar-

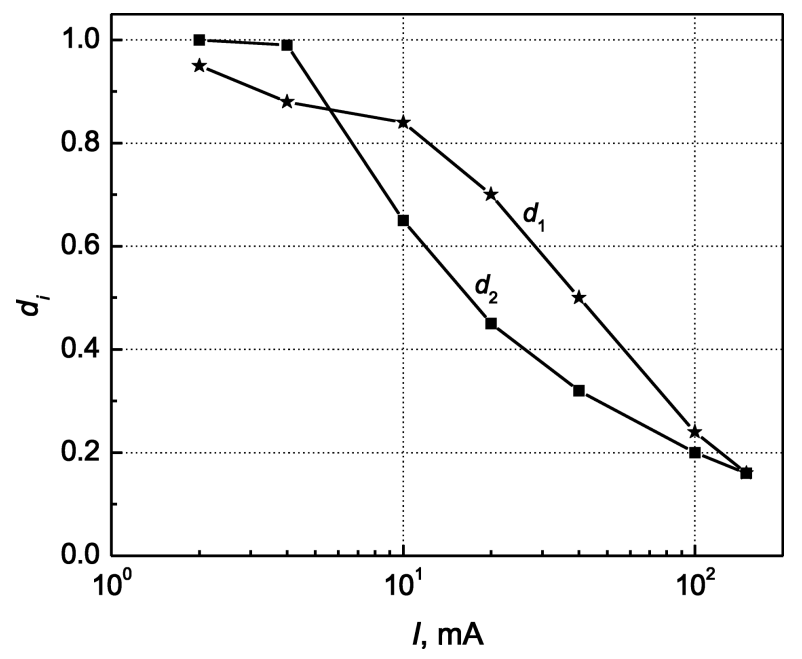

Fig. 11. Dependence of quantities $d_{j}$ on d. c. current.

ing the experimental data of correlation coefficient with that from Eq. (16). It is seen that $1 / f^{\alpha}$ type $(\alpha \approx$ 1.55) fluctuations have the larger contribution to correlation coefficient at lower frequencies, the contribution of fluctuations with Lorentzian type spectrum has a maximum at frequency $f=f_{0}=1 /(2 \pi \tau)$, while the contribution of $1 / f$ type fluctuations is sufficiently large in all frequency range. The dependence of correlation coefficient $r_{\text {oct }}$ on central frequency $f_{\mathrm{c}}$ of octave filter at different currents is presented in Fig. 10. The decrease of correlation coefficient at higher frequencies is due to larger contribution of noise with constant spectral density. The obtained results clearly show that correlation coefficient decreases with d. c. current increasing. In every octave the quantities $d_{j}$ were the same, they only depended on the type of low frequency fluctuations and on d.c. current of LED. The dependences of the quantities $d_{1}$ and $d_{2}$ on d.c. current is shown in Fig. 11. The fluctuations with Lorentzian spectrum were completely correlated $\left(d_{3}=1\right)$ in all measured d. c. current interval, but their contribution to the total correlation coefficient was noticeable only in the frequency range from $100 \mathrm{~Hz}$ to $1 \mathrm{kHz}$.

Dependence of correlation coefficient between electrical and optical fluctuations over frequency band from $10 \mathrm{~Hz}$ to $20 \mathrm{kHz}$ on d. c. current is presented in Fig. 12. Calculation results were obtained from Eq. (15) with the same quantities $d_{j}$ as in the case for one-octave frequency band (Figs. 10 and 11). It is clearly seen that there is a very good agreement between experimental and calculation results. 


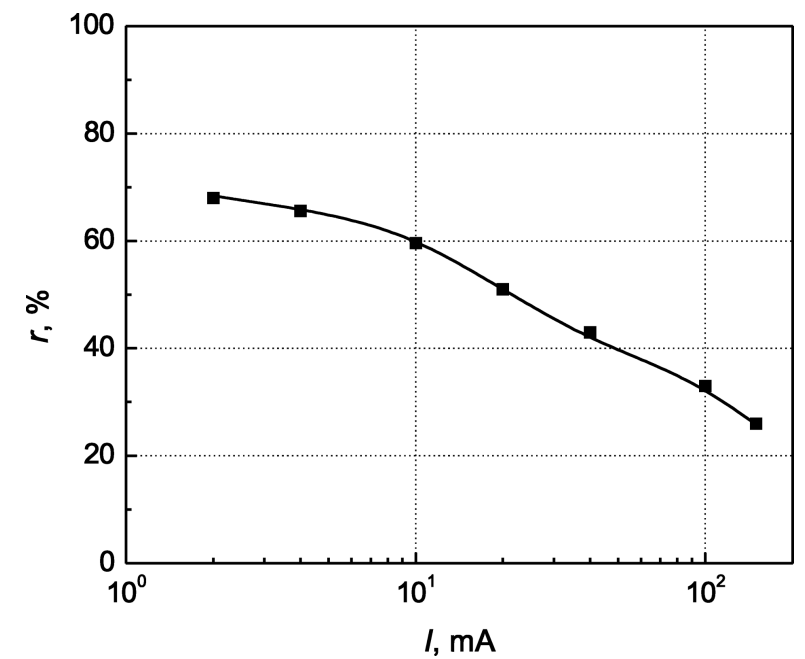

Fig. 12. Correlation coefficient $r$ between electrical and optical fluctuations in frequency band from $10 \mathrm{~Hz}$ to $20 \mathrm{kHz}$ dependence on d. c. current. Dots are measurement results, solid lines represent calculation data by Eq. (15).

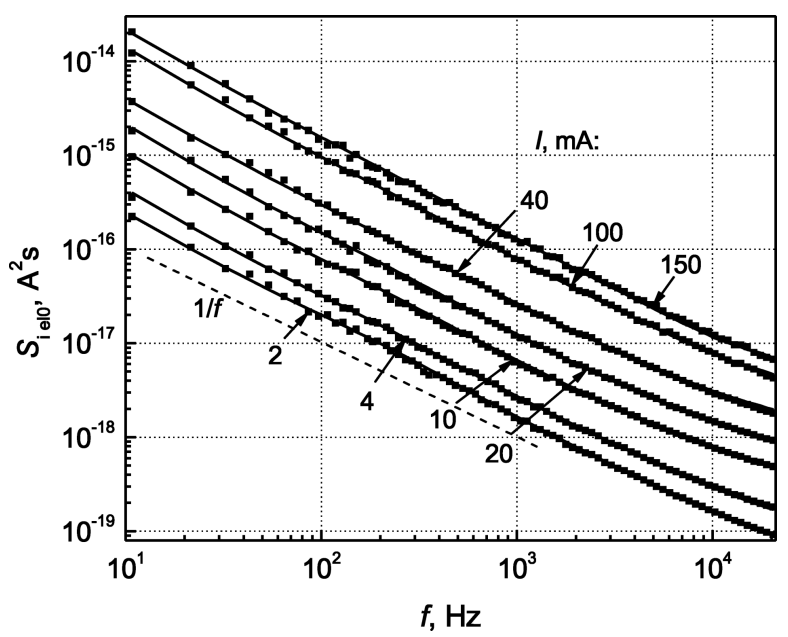

Fig. 13. Electrical noise current fluctuation spectral density dependence on frequency at different d.c. currents (here $S_{i \text { el0 }}=$ $S_{i \text { el }}-S_{i \text { el syst }}$. Dots are experimental results, solid lines are calculated by Eqs. (1) and (17).

\section{Discussion}

In order to clear up the origin of low-frequency fluctuations of LEDs and considering that light-emitting is due to charge carrier recombination process in the active $p-n$ junction layer of LED it is advisable to present the measured electrical and optical voltage fluctuation spectral densities as current fluctuation spectral densities:

$$
S_{i \mathrm{el}}(f)=\frac{S_{u \mathrm{el}}(f)}{R_{\mathrm{d}}^{2}} \quad \text { and } \quad S_{i \mathrm{ph}}(f)=\frac{S_{u \mathrm{ph}}(f)}{R_{\mathrm{ph}}^{2}},
$$

where $R_{\mathrm{d}}$ is the differential resistance of the LED $p-n$ junction, $R_{\mathrm{ph}}$ is the load resistance of the light receiv-

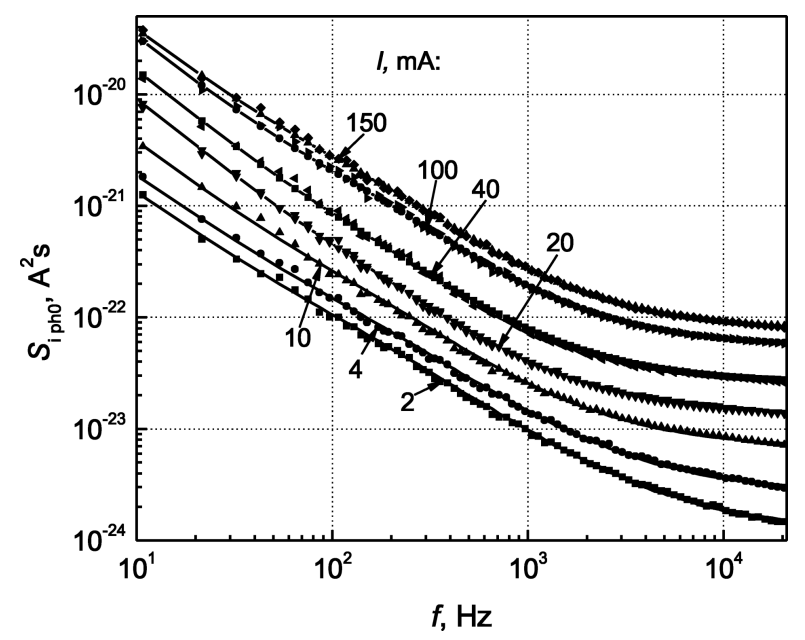

Fig. 14. Optical noise current fluctuation spectral density dependence on frequency at different d. c. currents (here $S_{i \mathrm{ph} 0}=S_{i \mathrm{ph}}-$

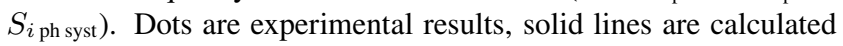
by Eqs. (2) and (17).

ing photodetector. The dependences of current fluctuation spectral densities (eliminating the own measurement system noises and thermal noise of load resistance $R_{\text {ph }}$ of photodetector) versus frequency at different d.c. currents are presented in Figs. 13 and 14. Both current fluctuation spectral densities are proportional to d. c. current. Eliminating the shot noise component (with constant spectral density) from the obtained results we can evaluate the simultaneous correlation coefficient in one-octave frequency range $r_{\text {lf oct }}$ including only low-frequency $\left(1 / f, 1 / f^{\alpha}\right.$, and Lorentzian type) fluctuations:

$$
r_{\text {lf oct }}=\frac{\sum_{j=1}^{3}\left(d_{j} \sigma_{j \text { l oct }}^{2} \cdot \sigma_{j \text { ph oct }}^{2}\right)^{1 / 2}}{\left(\sigma_{\text {el lf oct }}^{2} \cdot \sigma_{\text {ph lf oct }}^{2}\right)^{1 / 2}},
$$

where the variance

$$
\sigma_{\text {el lf oct }}^{2}=\sum_{j=1}^{3} \sigma_{j \text { el oct }}^{2} \text { and } \sigma_{\text {ph lf oct }}^{2}=\sum_{j=1}^{3} \sigma_{j \text { ph oct }}^{2} .
$$

The calculation results are presented in Fig. 15. It is seen that the correlation coefficient between lowfrequency electrical and optical fluctuations of LED only slightly depends on frequency, but it decreases with d.c. current (or emitting light power) increase. From the obtained results in Fig. 16 there are presented the current fluctuation variances (total, correlated, and uncorrelated parts) of low-frequency electrical noise dependence on d. c. current at three central frequencies $\left(f_{\mathrm{c}}, \mathrm{Hz}: 30,240\right.$, and 7680$)$ of octave filters. A total current fluctuation variance of electrical noise is approx- 


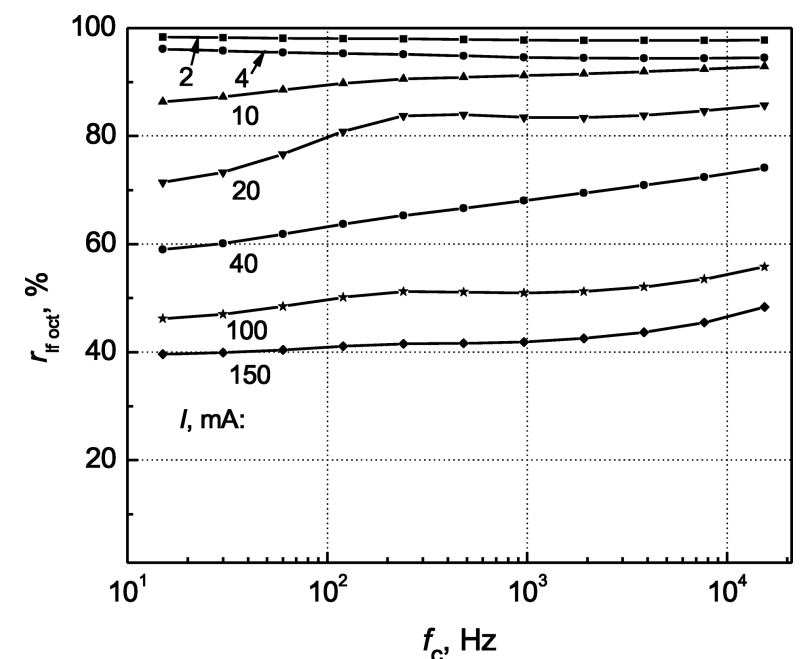

Fig. 15. Correlation coefficient between electrical and optical lowfrequency fluctuations (without both shot and measurement system noises) in one-octave frequency band $r_{\text {If oct }}$ dependence on central frequency $f_{\mathrm{c}}$ of octave filter at different d.c. currents.

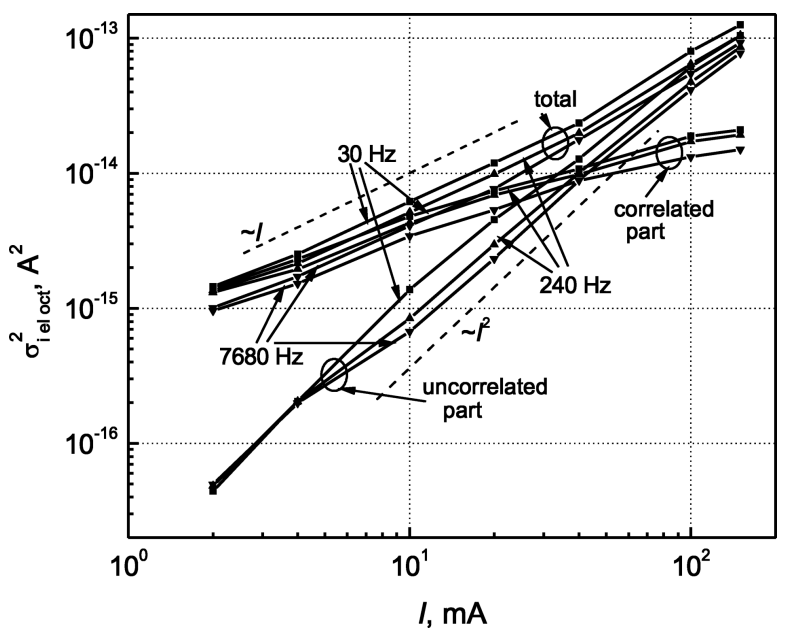

Fig. 16. The current fluctuation variance (total, correlated, and uncorrelated parts) of low-frequency electrical noise $\sigma_{i \text { el oct }}^{2}$ dependence on d.c. current at three central frequencies $(30,240$, and $7680 \mathrm{~Hz}$ ) of octave filters.

imately proportional to d.c. current. Such behaviour is characteristic of generation-recombination noise (the $1 / f$ and $1 / f^{\alpha}$ types of fluctuations are also a superposition of Lorentzian type random processes with appropriate relaxation time $\tau$ distribution): in linear samples $S_{i} / I^{2} \sim 1 / N$ (here $N$ is the total free charge carrier number in sample), but for $p-n$ junctions $N \sim I$, thus, the curent fluctuation spectral density $S_{i}$ and variance $\sigma_{i}^{2}$ for LEDs are proportional to $I$. On the ground of the fact that radiative recombination of charge carriers can occur only in the active layer of $p-n$ juncton we can state that correlated electrical and optical fluctuations are related with the active layer. There exist random potential fluctuations of parameters of quantum well due to charge carrier capture by defects in the active layer or to its interfaces. These potential fluctuations modulate that part of carriers which recombine in quantum well and produce the photons. Also we must have in mind that the larger part (over 85\%) of carriers recombines outside the active layer, where the non-radiative recombination time is very small, and consequently their contribution to the low-frequency noise level is also very small. A deviation of correlated part $\sigma_{i \text { corr }}^{2}$ of electrical fluctuation from proportionality to $I$ at higher d.c. currents can be explained by screening effect of electrical noise sources which cause the random modulation of light emission.

An uncorrelated part of current fluctuation variance $\sigma_{i \text { uncorr }}^{2}$ of electrical noise is $\sim I^{2}$, but the variance of voltage fluctuations $\sigma_{u \text { uncorr }}^{2}=\sigma_{i \text { uncorr }}^{2} R_{\mathrm{d}}^{2} \approx$ const. The obtained result can be explained in such a way: in parallel to $p-n$ junction there is a leakage channel (in surface regions or in other sites than the active layer) the resistance of which is many times higher than the resistance of $p-n$ junction, and the current fluctuations in this channel have no influence on optical power fluctuations.

\section{Conclusions}

A detailed analysis of electrical and optical fluctuations of high power LEDs was carried out. It was shown that decomposition of total low-frequency fluctuation spectrum into $1 / f, 1 / f^{\alpha}$, and Lorentzian type spectrum components is very useful for correlation analysis of noise properties. The correlation coefficient between electrical and optical fluctuations was evaluated not only over frequency range from $10 \mathrm{~Hz}$ to $20 \mathrm{kHz}$, but also for the first time in every one-octave frequency band. The presented technique permitted to determine the correlation coefficient dependence on frequency and to estimate what part to correlation coefficient is produced by low-frequency fluctuations with $1 / f, 1 / f^{\alpha}$, and Lorentzian type spectra, respectively: $1 / f^{\alpha}$ type $(\alpha \approx 1.55)$ fluctuations have the larger contribution to correlation coefficient at lower frequencies, the contribution of fluctuations with Lorentzian type spectrum has a maximum at frequency $f_{0}=1 /(2 \pi \tau)$ (here $\tau$ is the relaxation time of recombination process), while the contribution of $1 / f$ type fluctuations is sufficiently large at all frequencies. On the ground of obtained experimental results and calculation data we can state that the correlated part of electrical and optical fluctuations for the investigated LEDs is related with the defect presence in the active layer and its interfaces, 
while the uncorrelated part of electrical noise is caused by the parallel leakage channel the resistance of which is many times higher than that of the $p-n$ junction.

\section{Acknowledgement}

This work has been partially supported by the EU and Lithuanian SPD project No. BPD2004-ERPF-1.5.0-1205/0036.

\section{References}

[1] K.-M. Chang, J.-Y. Chu, and C.-C. Cheng, Highly reliable $\mathrm{GaN}$-based light emitting diodes formed by $\mathrm{p}-\mathrm{In}_{0.1} \mathrm{Ga}_{0.9} \mathrm{~N}-\mathrm{ITO}$ structure, IEEE Photon. Technol. Lett. 16, 1807-1809 (2004).

[2] S.J. Chang, L.W. Wu, Y.K. Su, Y.P. Hsu, W.C. Lai, J.M. Tsai, J.K. Sheu, and C.T. Lee, Nitride-based LEDs with $800^{\circ} \mathrm{C}$ grown p-AlInGaN-GaN double-cap layers, IEEE Photon. Technol. Lett. 16, 1447-1449 (2004).

[3] J. Han and A.V. Nurmikko, Advances in AlGaInN blue and ultravioletlight emitters, IEEE J. Select. Topics Quantum Electron. 8, 289-297 (2002).

[4] T. Mukai, Recent progress in group-III nitride lightemitting diodes, IEEE J. Select. Topics Quantum Electron. 8, 264-270 (2002).

[5] S.J. Chang, C.H. Kuo, Y.K. Su, L.W. Wu, J.K. Sheu, T.C. Wen, W.C. Lai, J.F. Chen, and J.M. Tsai, 400-nm
InGaN-GaN and InGaN-AlGaN multiquantum well light-emitting diodes, IEEE J. Select. Topics Quantum Electron. 8, 744-748 (2002).

[6] Y. Arakawa, Progress in GaN-based quantum dots for optoelectronics applications, IEEE J. Select. Topics Quantum Electron. 8, 823-832 (2002).

[7] M. Koike, N. Shibata, H. Kato, and Y. Takahashi, Development of high efficiency GaN-based multiquantum-well light-emitting diodes and their applications, IEEE J. Select. Topics Quantum Electron. 8, 271-277 (2002).

[8] V. Palenskis, Flicker noise problem, Lithuanian J. Phys. 30, 107-152 (1990).

[9] S. Pralgauskaite, V. Palenskis, and J. Matukas, Fluctuations of optical and electrical parameters of distributed feedback lasers and their reliability, Fluct. Noise Lett. 4, L365-L374 (2004).

[10] S.L. Rumyantsev, S. Sawyer, M.S. Shur, N. Pala, Y. Bilenko, J.P. Zhang, X. Hu, A. Lunev, J. Deng, and R. Gaska, Low-frequency noise of GaN-based ultraviolet light-emitting diodes, J. Appl. Phys. 97, 107-123 (2005).

[11] S. Pralgauskaitè, V. Palenskis, J. Matukas, J. Petrulis, and G. Kurilčik, Noise characteristics and reliability of light emitting diodes based on nitrides, Fluct. Noise Lett. 7, L367-L378 (2007).

[12] J. Matukas, V. Palenskis, J. Vyšniauskas, B. Šaulys, S. Pralgauskaitè, and A. Pincevičius, Noise characteristics and reliability of high power white light emitting diodes based on nitrides, Proc. SPIE 7142, 71420H171420H6 (2008).

\title{
KORELIACINE் ŠVIESOS DIODŲ ELEKTRINIŲ IR OPTINIŲ FLIUKTUACIJŲ ANALIZĖ
}

\author{
V. Palenskis, J. Matukas, B. Šaulys \\ Vilniaus universitetas, Vilnius, Lietuva
}

\section{Santrauka}

Pateikta detali didelès galios ( $3 \mathrm{~W}$ ) baltą šviesą spinduliuojančių diodų elektrinių (diodo įtampos) ir optinių (šviesos spinduliuotės galios) fliuktuacijų koreliacijos analizè. Tiriamų diodų pagrindą sudaro mėlynos šviesos InGaN diodai, kuriu paviršius padengtas YAG: $\mathrm{Ce}^{+3}$ fosforo sluoksniu, spinduliuojančiu plačiajuostę geltoną šviesą. Tyrimai atlikti kambario temperatūroje labai plačiame tiesioginès srovès intervale. Elektrinių ir optinių triukšmų spektrai ir koreliacijos koeficientas išmatuoti dažnių srityje nuo $10 \mathrm{~Hz}$ iki $20 \mathrm{kHz}$; be to, koreliacijos koeficientas pirmą kartą išmatuotas ir kiekvienoje nurodytos dažnių srities oktavos juostoje. Eksperimentiniai triukšmų spektrai skaičiavimo patogumui išreikšti $1 / f$, $1 / f^{\alpha}$ ir relaksacinio triukšmų spektrų suma. Toks triukšmo spektro išskaidymas i atskirus sandus patogus dar ir tuo, kad triukšmų šaltiniai, lemiantys šiuos triukšmų sandus, yra statistiškai nepriklau- somi, o tai labai palengvina elektrinių ir optinių fliuktuacijų koreliacijos analizę. Nustatyta koreliacijos koeficiento priklausomybė nuo oktavos juostos centrinio dažnio, atsižvelgiant tik i žemadažnius triukšmus: $1 / f^{\alpha}(\alpha \approx 1,55)$ triukšmo įnašas didžiausias yra tik žemuose dažniuose $(<1 \mathrm{kHz})$, generacinio-rekombinacinio (relaksacinio) triukšmo didžiausias įnašas yra esant dažniui $f_{0}=1 /(2 \pi \tau)$ (čia $\tau$ - relaksacijos trukmè), o triukšmo, turinčio $1 / f$ pavidalo spektrą, i̇našas i koreliacijos koeficientą yra didelis visame tirtame dažnių intervale. Ivertinta, kokia $1 / f$ ir $1 / f^{\alpha}$ elektrinio triukšmo (dispersijos) dalis lemia optinį triukšmą su tokiu pat spektru. Parodyta, kad koreliuotają elektrinio triukšmo dalį lemia defektai, esantys aktyviojoje šviesos diodo srityje, o nekoreliuotaja - srovès nuotẻkio kanalas, kurio varža yra žymiai didesnè nei diodo sandūros varža. 